\title{
Charcot, Janet, and French Models of Psychopathology
}

\author{
Olivier Walusinski ${ }^{a} \quad$ Julien Bogousslavsky ${ }^{b}$ \\ ${ }^{a}$ Family Physician, Private Practice, Brou, France; beurocenter, Swiss Medical Network, Clinique Valmont, \\ Glion/Montreux, Switzerland
}

\section{Keywords}

La Salpêtrière $\cdot$ Charcot · Janet · History of psychology ·

Hypnotism · Hysteria · Subconscious · Psychic automatism • Psychopathology

\begin{abstract}
Jean-Martin Charcot (1825-1893), thanks to his insight as a clinician can be said to be one of the precursors of scientific psychology. Charcot's 30 years of activity at La Salpêtrière hospital display an intellectual trajectory that decisively changed the idea of human psychology by favouring the emergence of two concepts: the subconscious and the unconscious. It was his collaboration with Pierre Janet (18591947), a philosopher turned physician, that led to this evolution, relying on the search for hysteria's aetiology, using hypnosis as a method of exploration. Focusing on clinical psychology that was experimental and observational, Janet built a theory of psychic automatism, "the involuntary exercise of memory and intelligence" leading to "independence of the faculties, freed from personal power." From all that came the idea of the subconscious, a functioning as a passive mental mechanism, resulting from a more or less temporary dissociation of previously associated mental content.
\end{abstract}

\section{Jean-Martin Charcot}

Jean-Martin Charcot (1825-1893) is recognized as one of the precursors of neurology, working in the second half of the 19th century in Paris (Fig. 1). During his training in various hospitals, it was not mental pathology that sparked his intellectual curiosity. In 1862, he was appointed to direct a department of chronic patients in what was originally a nursing home as well as an asylum, the Hospice de la Vieillesse Femmes de La Salpêtrière. Due to the dilapidated condition of the Sainte-Laure building, on the verge of collapse, the patients treated up to that point by the hospital alienist, Louis Delasiauve (1804-1893), were transferred in 1868 to the Petites Loges facility, which Charcot oversaw. This unexpected administrative decision led him to treat epileptics and hysterics. At the time, medical science regarded these pathologies with disdain, considering them of little interest. As Charcot put it: "A decision we did not ask for placed a department of nearly 150 beds under our responsibility. We can now observe all forms of epilepsy and serious hysteria" [1]. And in the words of the diarist Jules Clarétie (1840-1913): "Chance brought the

The two authors collaborated equally together on this article.

Dr. Olivier Walusinski

Family Physician, Private Practice

20 rue de Chartres

FR-28160 Brou (France)

walusinski@baillement.com 


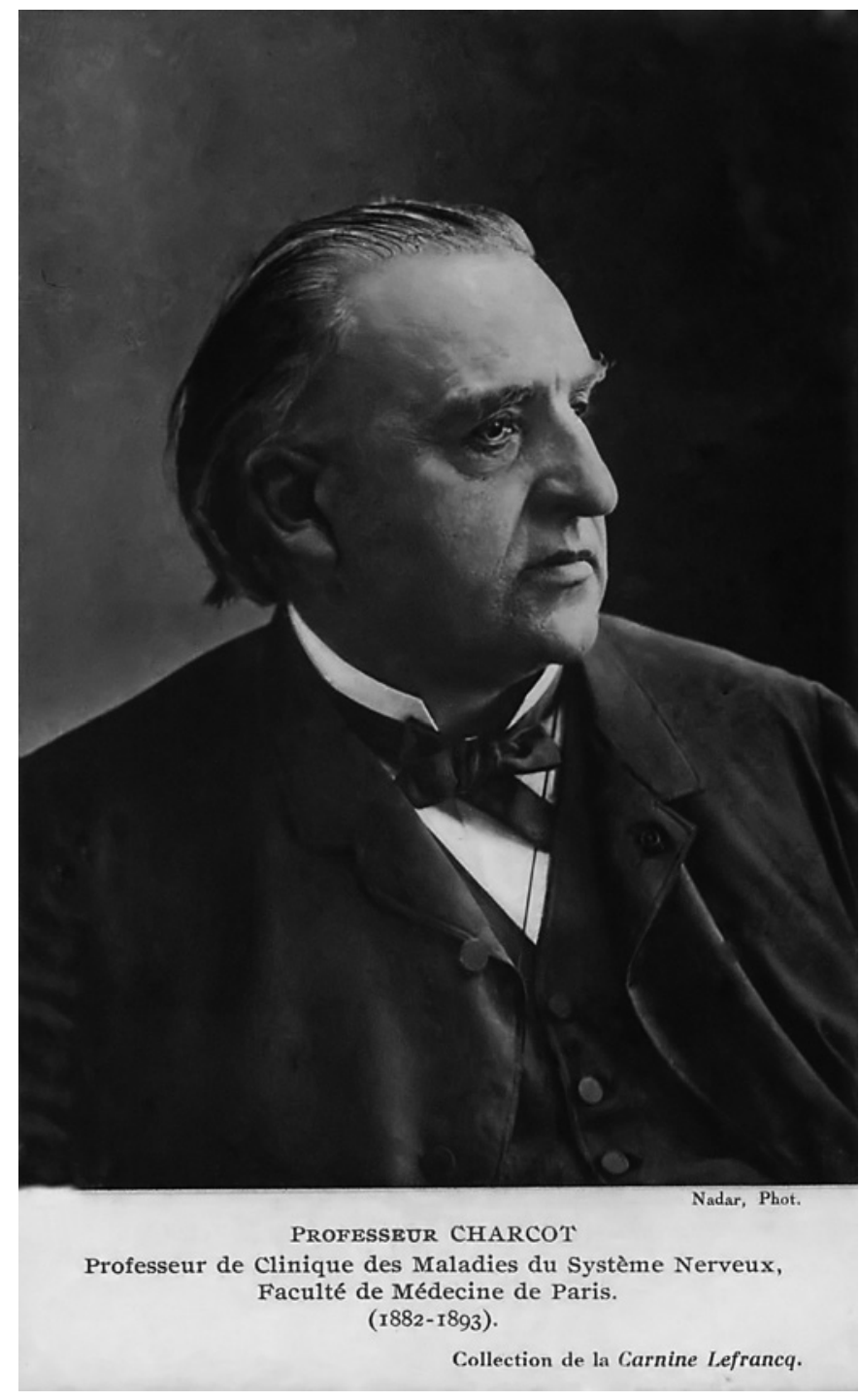

Fig. 1. Jean-Martin Charcot (1825-1893) (Collection OW).

situation about, from which science benefited" [2]. Taking on hysteria, with the invaluable assistance of his pupil Désiré Magloire Bourneville (1840-1909), Charcot display a trajectory of precursor of scientific psychology, availing himself of his discernment as a clinician. Charcot's 30 years of activity at La Salpêtrière hospital elucidate an intellectual trajectory that decisively changed the idea of human psychology by favouring the emergence of two concepts: the subconscious and the unconscious. "His work as a clinician-teacher, only establishing doctrine as tested by specific cases, which implied slow sedimentation and permanent revision, had the effect of refracting change." [3]. Charcot's constant modifications to his thinking made him a true researcher able to contradict himself, whereas the works of his students, Paul Richer (1849-1933) [4] and Georges Gilles de la Tourette (1857-1904) [5], at times suggest the edification of a closed, fixed dogma. The mythification of his work, and his research on hysteria in particular, was regarded with ambivalent fascination, more often leading to its unjust denigration than to the appreciation of the resulting concepts and advances, notably the accuracy of neurological examinations achieved by his student Joseph Babiński (1857-1932), which enabled distinguishing organic disturbances from functional disturbances $[6,7]$. This happened at a period during which the young Third Republic, imbued with positivism and to the slow evolution of a novel way of thinking, shaped by the imperious need to secularize medical thought and, in particular, the aetiology of mental diseases.

\section{Charcot and the Psychological Origin of Hysteria}

Early in his career, Charcot laid the ground for understanding the spinal and cerebral origins of paralysis, using the anatomo-clinical method, but starting in 1890, he identified, with the help of Pierre Janet (1859-1947), "diseases of representation," establishing their neurological as well as psychic functioning. After obstinately searching for a lesion in nervous system structures visible through the microscope that would explain hysteria, Charcot arrived at the concept of an abnormal idea, or a lesion in a representation. He used pathophysiological models (hysterogenic zones) and experimental physiology (hypnosis) to improve his understanding of hysteria, then attributed to trauma the psychophysiological explanation of a causal agent (interior mental work). Starting with his 1870 lessons, his use of the analogy of his observations and the miraculous cures reported by the lexicographer Émile Littré (1801-1881) in his Philosophie positive indicate that the psychic matrix of hysteria was implicitly integrated, and from an early phase, in his thinking. The clarification of the extraordinary facts disseminated by religion, based on a psychic explanation, is another constant in Charcot's work and that of his students. According to his biographer Paul Peugniez (1859-1943): "He had to have unshakable faith in his doctrine, and especially needed his extraordinary mental lucidity to risk studying these discredited subjects, to lift the veil that had terrified others upon their merely encountering it, the veil that had halted the most learned and accomplished men, including Lasègue. No other professor with an official chair had attempted to study these occult phenomena, which since Antiquity had fascinated public opinion" [8]. 


\section{Charcot and Hypnosis}

Charcot presented the use of hypnosis as an experimental technique, without any attempt to turn it into a therapy, on February 13, 1882. He sought to strengthen his candidacy for the French Academy of Sciences even though the Chair of Nervous System Diseases had recently been created for him. He entitled his presentation: "Sur divers états nerveux déterminés par l'hypnotisation chez les hystériques (On various nervous states determined by hypnotisation in hysterics)" [9]. He distinguished three phases in hypnotism: lethargy, catalepsy, and somnambulism, recalling what the physician Charles-Humbert Despine (1777-1852) had written as early as 1840 [10]. The scientific backing that Charcot lent to hypnosis rehabilitated it and enabled Paul Richer (1849-1933), followed by Georges Gilles de la Tourette (1857-1904) and other La Salpêtrière students, and then Janet, to use it for their own experimental research on the "mental state of hysterics," the subject of Janet's thesis for his doctorate in medicine, presided over by Charcot on July 29, 1893, 2 weeks before the Master's death [11]. In the preface, Charcot wrote for the commercial version of Janet's thesis, he noted: "The studies of my student Janet confirm the thinking often expressed in our lessons, namely that hysteria is largely a mental illness. This is one aspect of the disease that we must never neglect if we wish to understand and treat it" [12]. Freed of the supernatural, hypnosis became the validated experimental model of hysteria: "Between the organism's regular functioning and the spontaneous disturbances caused by the disease, hypnotism becomes an approach open to experimentation. The hypnotic state is nothing but an artificial or experimental nervous state, the multiple manifestations of which appear or disappear according to the needs of the study and the wishes of the observer. Seen in this light, hypnotism becomes ground to be mined, yielding precious results for the physiologist and the psychologist, as well as for the physician" [13]. Abandoning the quest for a lesion, and using a psychic aetiology for hysteria, Charcot opened the way to theoretical study and conceptualization not only by Pierre Janet but also by the first neuropsychologist Paul Sollier (1861-1933) and Sigmund Freud (1856-1939) and probably did not even realize the full scope of his approach for later researchers. This development did not mask his constant desire to integrate hysteria in the neurological nosography, along with all the other diseases he had been the first to identify and describe. This would mean that hysteria, a nervous system condition, would have a cause explained by a rational

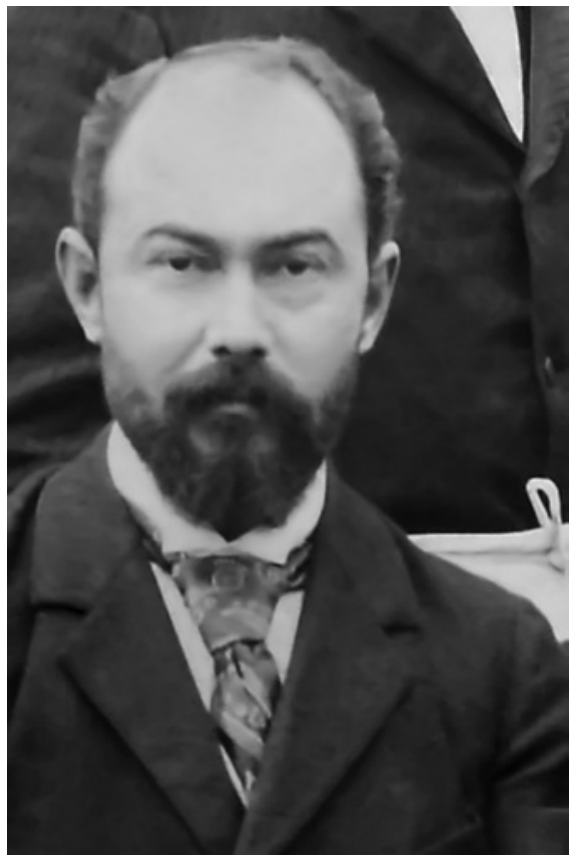

Fig. 2. Pierre Janet (1859-1947) (Collection OW).

physiology of the cerebral cortex, whereby psychology would pass as a science [14]. In an article on Charcot, Janet concluded: "Charcot did not invent hypnotism; this cannot be denied. He was not even the first to note its psychological value, but he did reveal it. Thanks to the considerable authority of his name, he was able to fully elucidate facts that until then had been observed in the shadows and to bring science to bear in areas previously surrounded by mystery and superstition" [15].

\section{Pierre Janet}

Pierre Janet was born in Paris on May 30, 1859, to a family of office employees and thus of modest means (Fig. 2). His uncle was the philosopher Paul Janet (18231899). At the École Normale Supérieure, he began preparing for the competitive exam to become a philosophy professor, along with Henri Bergson (1859-1941), Emile Durkheim (1858-1917), and Jean Jaurès (1859-1914). At the same time, he worked as an assistant to Albert Dastre (1844-1917), a physiology professor at La Sorbonne. This activity served as the equivalent of the first 2 years of medical school. After passing the philosophy agrégation exam on September 07, 1881, he began teaching at the secondary school in the northwestern French city of Le Havre in 1883. Le Havre was a maritime, industrial, and commer- 
cial centre from which it was quick and easy to reach Paris. Janet, thus, frequently visited his family and participated in the intellectual milieus he found enriching [16].

$\mathrm{He}$ initially planned to study hallucinations for his doctoral thesis in literature. By chance, one of his students was the son of a physician at the hospital, Joseph Gibert (1829-1899), and Janet got to know him and spent time in the department he directed with Léon-Jean Powilewicz (1852-1932), a department known for treating all "the neurotics in Normandy." Influenced by the teaching of the philosopher Théodule Ribot (1839-1916) and by his old friendship with the future Nobel Prize recipient Charles Richet (1850-1935) [17], Janet came up with the idea of using a mental pathology, hysteria, of which there were several cases in Gibert's department, as a natural experimental condition, presaging Ribot's words in 1909: "The pathological method is based on both pure observation and experimentation. Disease is the most subtle form of experimentation, instituted by nature itself in specific circumstances and with processes that human art lacks. In this way, disease attains the inaccessible" [18]. Janet conducted his own hypnosis experiments in an attempt to elucidate the pathophysiology of hysteria, similar to what Charcot had been studying with his residents at La Salpêtrière for over 10 years. Janet initially focused on the case of 1 female patient, the "clairvoyant and magnetist Léonie," a 40-year-old servant from Normandy whom Gibert had catalogued as a "somnambulant hysteric." Charcot accepted Gibert's invitation to come to Le Havre in 1885 and examine this famous Léonie, along with other members of the French Society of Physiological Psychology, created with Ribot and Richet that same year. This first meeting with Charcot reoriented Janet's career, first through the access he gained to the Clinic of Nervous System Diseases at La Salpêtrière, where he observed consultations, and more broadly, through his decision to pursue medical studies.

Janet described Léonie's case this way: “This young woman was brought from the country to the Le Havre hospital at the age of nineteen, because she was considered crazy and there was almost no hope for a cure. In reality, she had periods of convulsive attacks and delirium that went on for days. After a time of observation, it was easy to see that the disease involved periodic accidents that recurred regularly with menstruation and other less serious accidents occurring irregularly in the intervals and extending over time. Regarding the first type of accident, Marie's character changed as her periods approached; she became dark and violent, unusual for her, and she experienced pain and nervous shaking in all

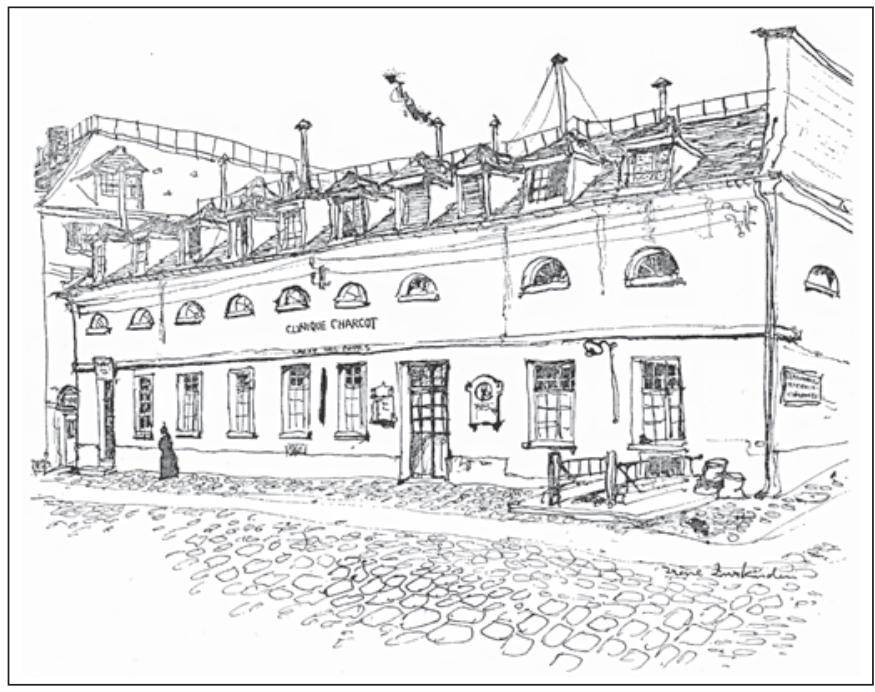

Fig. 3. Outpatients department at La Salpêtrière in the time of Charcot, engraving by Irène Zurkinden (1909-1987) (Collection OW).

limbs..." In addition to this clinical case, he collated observations and experiments that he had conducted with 19 hysterics of both genders and with 8 psychotics and epileptics to provide material for his doctoral thesis in literature, defended in 1889, entitled L'automatisme psychologique, essai de psychologie expérimentale sur les formes inférieures de l'activité humaine (Psychological automatism, an experimental psychology essay on the inferior forms of human activity) [15], a powerful first draft containing the main ideas that Janet would develop over half a century.

\section{Janet and Psychic Automatism}

Already in 1845, the alienist at La Salpêtrière (Fig. 3), Jules Baillarger (1809-1890), put forward an outline of a theory of psychic automatism, "the involuntary exercise of memory and intelligence" leading to "independence of the faculties, freed from personal power" [19]. In the diseases of personality, especially disturbances linked to multiple personalities, Janet recognized the means of studying the phenomena of consciousness. He introduced the idea of the subconscious, "which is below consciousness, but of the same nature," to explain cases of double personality, initially, from a distinctly more philosophical than medical perspective. In his thesis, Janet revealed his Cartesian materialism in analysing the mental state of his patients before, during, and after hypnotic 
suggestion, thereby establishing a descriptive, structural study of hypnosis. He can be said to have recycled the analysis proposed by Charcot in his dissertation as a candidate for the French Academy of Sciences, defining catalepsy, lethargy, and somnambulism as "inferior forms of mental life" [20]. Present in normal humans, they are characterized by a mental state outside voluntary control, thus becoming the source of behaviours that appear automatic, uncontrolled. To describe it without any relation to lesional activity in the nervous system, Janet introduced the idea of the subconscious, rather than the unconscious, whose manifestation would be considered to underlie a loss of functional (or lesional) activity in the brain. He thought of its functioning as a passive mental mechanism, resulting from a more or less temporary dissociation of previously associated mental content. Any individual could experience this dissociation, either spontaneously or following trauma (accident, rape, etc.), or experimentally, as occurs in hypnosis. His own familiarity with the old practices of magnetism probably led Janet to these conclusions. He ended up interpreting the dissociative fact or "mental disintegration" as the cause of all mental illnesses. As part of a single personality, the healthy individual integrated and produced memories and actual external (from the senses) and internal perceptions (or cenaesthesia, i.e., the internal perception of our own body or interoception), making him or her conscious of his or her own identity. The weakening of this concatenation by a psychological injury created the state of mental disintegration that prevented the sick individual from recognizing certain memories of facts, even though they had actually been encountered, as his or her own personal experience. The importance Janet accorded to suppressed memories led him to a new psychogenesis centred on different types of recollections and capacities of cued recall for remembrance. Was this based on chance coincidence? In the years that followed, Marcel Proust (1871-1922) created his novel $A$ la recherche du temps perdu (In Search of Lost Time) by applying these approaches and the one that is, the involuntary memories triggering re-experiencing, a new explanation he learned when he stayed under the care of Paul Sollier [21]. Janet used his theory to achieve a conceptual tour de force, that of confirming classical philosophy, based on an introspective approach, all while giving psychiatric semiology a psychophysiological basis that was truly cerebral.

It must be recalled that, as a tool for exploring the depths of the psyche, automatic writing occupied an initiatory place in Surrealism's identity. But André Breton (1896-1966) had systematically failed to acknowledge publicly that he had read and reread Pierre Janet's book L'Automatisme psychologique[22].

In 1889 , the first international conference on experimental and therapeutic hypnotism was held from 8 to 12 August at Hôtel-Dieu hospital in Paris. Charcot was the honorary president, and the reports were written by the physician Edgar Bérillon (1859-1948). His teacher, Victor Dumontpallier (1826-1899), presided over the debates, an occasion for Gilles de la Tourette and the Nancy's physician Hippolyte Bernheim (1840-1919) to face off once again on the powers of suggestion. Many presentations dealt with the therapeutic use of hypnosis, an objective that Charcot had always refused to consider [23]. In studying hysteria by means of hypnosis, Charcot placed emphasis on the psychological aetiology of the neuroses, and he had no wish to go any further. The debate between the Nancy and Salpêtrière schools was focused around a few cases of crime committed allegedly under hypnosis. Unlike Bernheim, for Charcot's pupils, subjects are unable to commit crime under hypnosis. The controversy between these two schools affected medical, legal, and public in the Belle Époque [24].

The psychiatrist Auguste Forel (1848-1931) from Switzerland gave a presentation in which he drew a parallel between the hypnotic state and "negative hallucination in lunatics" (the absence of image in the mirror, e.g., in the novel Le Horla by the writer Guy de Maupassant), that is, suggesting homology between the two dissociated states. He also put forward this thesis in a book he published around the same time in German: Der Hypnotismus, seine Bedeutung und seine Handhabung (Hypnotism, its meaning and its handling) [25]. The conference concluded with an extensive visit of La Salpêtrière, with Charcot hosting some 100 participants at the Clinic of Nervous System Diseases.

\section{Janet at La Salpêtrière}

Undoubtedly impressed by the originality of Janet's thesis and its influence, Charcot offered him a position in 1890 at the head of "a psychology laboratory" within the Clinic of Nervous System Diseases and aligned with his thinking, as he expressed it during the lesson of Tuesday, January 17, 1888: "We must create a psychology that is strengthened by the pathological studies we are conducting. This is what we are doing with psychologists who, this time, are willing to not exclusively consider what we call interior observation" [26]. After initially turning to Ribot, a pure philosopher, Charcot placed his hopes in the 
younger Janet, soon to be a physician, for a psychopathological explanation of hysteria. Janet directed the Salpêtrière laboratory, created expressly for him, with the constant support of Charcot's successor, Fulgence Raymond (1844-1910), with whom he published two books: Névroses et idées fixes (Neuroses and fixed ideas) in 1898 and then Les obsessions et la psychasthénie (Obsessions and psychasthenia) in 1903. However, Jules Dejerine (1849-1917), Charcot's third successor, dismissed him and opposed his election to the French Academy of Medicine. The alienist-physician and neuropathologist Jean Nageotte (1866-1948) gave Janet a small office so that he could continue working at La Salpêtrière. Probably out of nostalgia, Janet continued all his life to publish his major works under the auspices of the Salpêtrière psychology laboratory, even though it no longer existed [27, 28]. For Janet, the apogee of all his efforts was his election to the Chair of Experimental Psychology at the Collège de France in January 1902, where he had been Ribot's replacement in this chair since 1895 . He would remain in this position until 1934.

After Charcot's death, Fulgence Raymond remained faithful to the concepts developed by Charcot, enriched by Janet's contributions, in particular regarding the reality of hysteria in men, which Gilles de la Tourette continued to support as well [5]. As for Babiński [29], he renounced his initial ideas [30], aligning himself instead with the concepts defended by Bernheim and the Nancy School. For them, the physical and mental automatisms of hysterics and hypnotized patients were nothing more than the exaggeration of ordinary behaviours observable in all people, explained by natural credulity, for which Bernheim coined the term "crédividité naturelle." Hypnosis was merely the augmentation by suggestion of an innate human capacity, or passive obedience [31, 32]. The public demonstrations at La Salpêtrière were nothing more than the product of the culture of suggestion there.

Whereas the influence of Wilhelm Maximillian Wundt (1832-1920) in Germany oriented psychology towards a science that measured psychic functions, Janet focused on clinical psychology that was experimental and observational: "The method we have tried to implement, without any pretension of having succeeded, is the method of the natural sciences [...]. We have collected facts through observation; that is, the simple actions we wished to study [...]. Undoubtedly, we only have indirect knowledge of the psychological phenomena in other people, and psychology could not start by studying them; but according to actions, gestures, and language, we can induce their existence, in the same way the chemist determines the elements in stars from the rays of the spectrum, and the certainty of one type of operation is as great as that of the other" [15].

\section{Janet's Contributions to Psychology}

Throughout the years he taught at the Collège de France, Janet used the same explanatory principles; that is, the dissociation of memories and somaesthesic perceptions, between the conscious and the subconscious, the loss of ability to appreciate reality, when he studied fatigue (1902), emotion (1903), movement (1904), hysteria (1905), and psychasthenia (1906). Similar to John Hughlings Jackson (1835-1911) [33], he enriched this approach by incorporating the Theory of Evolution of Charles Darwin (1809-1882) and its extension into realms of sociology by Herbert Spencer (1820-1903) to show that psychological disorders, classified based on a scale of complexity, proceed from the inferior to the superior, that is, in the opposite direction of phylogenetic improvements, or ontogenetic progress. In this way, Janet was a precursor to behaviourism. In 1926, Janet proposed nine levels of psychic functioning in his De l'angoisse à l'extase (From anxiety to ecstasy). His propositions can be simplified as follows: agitation without any purpose emerges before language and corresponds "to the lowest actions, those that reappear when more suitable and superior actions are excluded or become insufficient." Elementary mental operations give rise to symbols and language which memory underlies. For example, beliefs can be divided into "assertive beliefs," that is, those linked to desire, resulting in great variability, and manifesting themselves in the process of suggestion (for Janet, they were at the root of legends and religious beliefs) and into "reflected beliefs," that is, those "reproducing inside ourselves the discussion of an assembly and preventing assent until internal discussion has taken place," Finally, rational behaviours along with executive, experimental, and elaborate conduct correspond to the highest development of individual action and can be associated with the concept of progress and seeking progress, whatever the forms.

Janet also developed the dynamic aspect of psychology by hypothesizing psychic energy, that is, by examining the capacity to support a number of psychological acts over time. The variability of these parameters takes account of the capacity to support the duration of psychic tension. The highest level results in successful social be- 
haviour that is harmonious in one's interactions with others and in line with reality. Deductions from these findings have become common knowledge, involving psychological strength or weakness in the face of contingencies in family or professional life. Janet's psychology, thus, dealt with the psychic energy and dynamics of behaviour.

\section{Janet as Therapist}

Janet did not forget that he was a physician and in 1923 released his La médecine psychologique (Psychological medicine), which expanded upon Les médications psychologiques (Psychological medications), published in 1919. The book started with a history of psychotherapies, the earliest of which Janet likened to religious practices and miracles. He went on to draw a parallel with "animal magnetism" and the practices of hypnosis at the end of the 19th century. In a section entitled "The clearance of traumatic memories," Janet made the following argument: "While treatments using aesthesiogenesis have not had a brilliant career until now, the same is not true for seeking out traumatic subconscious memories, which I have identified in studies on somnambulism and which have given rise to various sects of psychoanalysis. There has been considerable development of a psychotherapeutic practice that recalls the enthusiasts for mesmerism, Christian Science, or hypnotism." Undoubtedly surprised by the dissemination of Sigmund Freud's ideas, he expressed bitterness at being stripped of his own ideas and theories: "At that time, a foreign physician, Dr. S. Freud (from Vienna), came to La Salpêtrière and became interested in these studies; finding the facts to be based in reality, he published new observations of the same type. In these publications, he first changed the terms I used, referring to psychoanalysis for what I had called psychological analysis, and to a complex for what I had called a psychological system, which indicates all facts related to conscience and movement, whether in the limbs or the viscera, and which on the whole comprises the traumatic memory. What I considered a reduction of consciousness, he saw as repression; to what I called psychological dissociation or moral disinfection, he gave the name of catharsis. But most importantly, he transformed clinical observation and a therapeutic process with specific and limited indications into a vast system of medical philosophy" [34]. Imbued with his discovery of psychological automatism, Janet argued for the practice of hypnotic suggestion and for directively shaping the patient's behav- iour ("acquisition and fixation of new tendencies"), which form the basis for current cognitive-behavioural therapy. Janet also argued for motivating behaviours (which he called excitations), whereas previously Paul Dubois (1848-1918) in Bern and Jules Dejerine (1849-1917) had used prolonged bed rest with a milk-rich diet (infantile regression) $[21,35,36]$. The following passage from his writings could have served as a conclusion for him and expresses a form of pessimism: "It is easy to see that these diverse psychotherapies all have a strange progression: they emerge suddenly, pridefully assert that they alone are powerful and useful treatments, then invade the world with the speed of an epidemic, before gradually or suddenly losing influence and becoming ridiculous or forgotten" [34].

\section{In Perspective}

Janet's capacity, heightened at the end of his career, to integrate the social context, notably through the hierarchy of behaviours, into his psychological research, underscored his perseverance in incorporating his studies into real life. This prevented him from becoming cut off through a purely academic science.

"Janet is a striking example of the way in which fame and oblivion are unequally distributed among scientists. In 1900, his contemporaries had the impression that he would soon become the founder of a great school. However, despite the constant development of his work, it seemed he gradually drifted away from the general trend. Many psychiatrists and psychologists, as well as cultured persons, still regarded him exclusively as the author of the psychological automatism and as the consultant who had exactly described obsessive neuroses. Comparatively few people seemed to realize that he was creating a synthesis of enormous scope and dimensions" [37]. This sentence from Henri Ellenberger (1905-1993) partly explains the long "purgatory" endured by Janet. Sacha Nacht (19011977) concluded at best: "Janet has shown us how and Freud why. And some tend to forget about the how" [38]. Thanks to Charcot allowing Janet to become a physician while remaining a philosopher. So, he prepared the advent of modern psychiatry and of psychology, the organo-dynamism by Ey, the notion of dissociation, the debate around relations between cerebral physiology and psychology. 


\section{Acknowledgements}

Many thanks to Jacques Poirier and Hubert Déchy for their attentive readings and suggestions and to Anna Fitzgerald for her translation.

\section{Statement of Ethics}

The authors have no ethical conflicts to declare.

\section{Disclosure Statement}

No potential conflict of interest was reported by the authors.

\section{Funding Sources}

The authors received no financial support for the research, authorship, and/or publication of this article.

\section{References}

1 Charcot JM. Leçons sur les maladies du système nerveux recueillies et publiées par Bourneville. Paris: A. Delahaye; 1872.

2 Clarétie J. Charcot le consolateur. Les Annales Politiques Littéraires. 1903;21:79-80.

3 Gauchet M, Swain G. Le vrai Charcot, les chemins imprévus de l'inconscient. Paris: Calmann-Lévy; 1997.

4 Richer P. Études cliniques sur l'hystéro-épilepsie, ou Grande hystérie. Paris: Delahaye et Lecrosnier; 1881.

5 Gilles de la Tourette G. Traité clinique et thérapeutique de l'hystérie d'après l'enseignement de la Salpêtrière. Paris: E. Plon, Nourrit et Cie; 1895.

6 Babiński J. Contractures organique et hystérique. Bull Mem Soc Med Hop Paris. 1893; 10(3):867-70.

7 Babiński J. Diagnostic différentiel entre l'hémiplégie organique et l'hémiplégie hystérique. Gaz Hop Civ Mil. 1900;73:521-33.

8 Peugniez P. J.M. Charcot 1825-1893. Amiens: Imp. Picarde. 1893.

9 Charcot J. Physiologie pathologique: sur divers états nerveux déterminés par l'hypnotisation chez les hystériques. C R Acad Hebd Séances Acad Sci. 1882;94:403-5.

10 Despine C-H. De l'emploi du magnétisme animal et des eaux minérales dans le traitement des maladies nerveuses, suivi d'une observation très curieuse de guérison de névropathie. Paris: Germer-Baillière; 1840.

11 Janet $\mathrm{P}$. Contribution à l'étude des accidents mentaux chez les hystériques. Thèse Paris $N^{\circ} 432$ : Rueff; 1893.

12 Janet P. État mental des hystériques: les stigmates. Paris: Rueff et Cie; 1893.

13 JanetPJM. Charcot, son œuvre psychologique. Revue Philosophique. 1895;14:569-604.
14 Goetz C, Bonduelle M, Gelfand T. Charcot: Constructing Neurology. New York, Oxford: Oxford University Press; 1995.

15 Janet P. L'automatisme psychologique, essai de psychologie expérimentale sur les formes inférieures de l'activité humaine. Thèse d'État, Faculté des lettres. Paris: Félix Alcan; 1889.

16 Pichon-Janet H. Pierre Janet quelques notes sur sa vie. L'Évolution Psychiatrique 1950; 15(3):345-55

17 Richet C. Les démoniaques d'aujourd'hui: l'hystérie et le somnambulisme. Revue Mondes. 1880;37:340-72.

18 Ribot T. De la méthode dans les sciences. Paris: Félix Alcan; 1909.

19 Baillarger J. Recherches sur les maladies mentales. Paris: Masson; 1845

20 Janet P. Les formes inférieures de l'activité normale. Revue l'Hypnotisme. 1889;4:14-21.

21 Bogousslasky J, Walusinski O. Paul Sollier: the first clinical neuropsychologist. Front Neurol Neurosci. 2011;29:105-14.

22 Bacopoulos-Viau A. Automatism, surrealism and the making of French psychopathology: the case of Pierre Janet. Hist Psychiatry 2012; 23(3):259-76

23 Bérillon E, editor. Premier congrès international de l'hypnotisme expérimental et thérapeutique. Paris: Octave Doin; 1890.

24 Piechowski-Jozwiak B, Bogousslavsky J. Hypnosis and the Nancy quarrel. Front Neurol Neurosci. 2014;35:56-64.

25 Forel A. Der Hypnotismus, seine Bedeutung und seine Handhabung. Stuttgart: Enke; 1889.

26 Charcot JM. Leçons du Mardi à La Salpêtrière. Policliniques 1887-1888. Paris: Aux Bureaux du Progrès médical; 1888.
27 Couchet JL. Janet à La Salpêtrière. L'Évolution Psychiatrique. 1950;15:357-64.

28 Allilaire J. Pierre Janet et La Salpêtrière. Ann Médico-Psychologiques. 2008;166:185-90.

29 Babiński J. Ma conception de l'hystérie et de l'hypnotisme (pithiatisme). Conférence faite à la Société de l'internat des Hôpitaux de Paris le 28 juin 1906. Chartres: imp. Durand; 1906.

30 Babiński J. Démembrement de l'hystérie traditionnelle: pithiatisme. Paris: Imprimerie de la "Semaine médicale"; 1909.

31 Bernheim H. De la suggestion dans l'état hypnotique et dans l'état de veille. Paris: Octave Doin; 1884.

32 Bernheim H. De la suggestion et de ses applications à la thérapeutique. Paris: Octave Doin; 1886.

33 Jackson JH. The Croonian lectures on evolution and dissolution of the nervous system: delivered at the Royal College of Physicians. Zurich: Orell Füssl; 1921.

34 Janet P. La Médecine psychologique. Paris: Flammarion; 1923.

35 Pérez-Rincón H. Pierre Janet, Sigmund Freud and Charcot's psychological and psychiatric legacy. Front Neurol Neurosci. 2011;29:11524.

36 Compagnon A. Surprenant C. Freud at the Collège de France. Paris: Éditions du Collège de France; 2018.

37 Ellenberger $\mathrm{H}$. The discovery of the unconscious: the history and evolution of dynamic psychiatry. London: Allen Lane, The Penguin Press; 1970

38 Nacht S. De la pratique à la théorie psychanalytique. Paris: Presses Universitaires de France; 1950 